Recommended citation:

Raphaële Xenidis, 'Multiple Discrimination in EU Anti-Discrimination Law

Towards Redressing Complex Inequality?' in Uladzislau BELAVUSAU and Kristin HENRARD (eds), EU anti-discrimination law beyond gender (Oxford ; Portland : Hart Publishing 2018), pp. 41-74 .

\title{
Multiple Discrimination in EU Anti-Discrimination Law Towards Redressing Complex Inequality?
}

\author{
Raphaële Xenidis*
}

\section{Introduction}

The complete overhaul of EU anti-discrimination law at the beginning of the 2000s triggered discussions on the necessity to tackle an issue which had been gaining attention since the end of the 1990s in Europe - multiple discrimination. Multiple discrimination pertains to situations in which a person is discriminated against on more than one ground. Let us take as an example a case of workplace discrimination against an EU citizen - a Muslim woman wearing an Islamic headscarf. Such a case might involve harmful stereotypes based on religion, but also on race and gender. ${ }^{1}$ Do litigators and courts need to pick and choose a ground? Would a claim of multiple discrimination make a difference in terms of protection of rights or legal reasoning?

Intersectionality theory postulates that certain experiences of multiple discrimination cannot be adequately grasped and remedied by the law unless examined from the angle of the 'synergies' of the different grounds involved. ${ }^{2}$ In our example, the experience of

\footnotetext{
* I am grateful to my $\mathrm{PhD}$ supervisor Claire Kilpatrick, to Bruno De Witte, to my friends and colleagues at the EUI Shreya Atrey, Lilla Farkas and Liiri Oja, to the editors of this book Uladzislau Belavusau and Kristin Henrard for their invaluable comments on this piece and to Marguerite Bolger, Mary Collins, David Fennelly, Joanna Maycock. David Parris, Jyostna Patel and Jean Tomkin for sharing their insights and stories with regard to some of the cases examined in this chapter.

${ }^{1}$ On religious discrimination, see the chapters by E Relaño Pastor and A Śledzińska-Simon in this volume. On the construction of race in Europe, see M Möschel, Law, Lawyers and Race: Critical Race Theory from the United States to Europe (New York, Routledge, 2014) and on the racialisation of religious groups, see, eg N Meer (ed), Racialization and Religion: Race, Culture and Difference in the Study of Antisemitism and Islamophobia (New York, Routledge, 2014).

${ }^{2}$ On the theorisation of intersectionality, see K Crenshaw, 'Mapping the Margins: Intersectionality, Identity Politics, and Violence against Women of Color' (1991) 43 Stanford Law Review 1241; K Crenshaw, 'Demarginalizing the Intersection of Race and Sex: A Black Feminist Critique of Antidiscrimination Doctrine, Feminist Theory, and Antiracist Politics' (1989) 1 The University of Chicago Legal Forum 139; I Solanke, Discrimination as Stigma: A Theory of Anti-discrimination Law (Oxford, Hart, 2017) 133-159.
} 
discrimination could arguably involve islamophobia, where racist prejudices blend with religious and cultural animosity. It would, however, also imply a gendered dimension, since the Islamic headscarf only pertains to women. ${ }^{3}$ Consider the concrete case of an employer who adopts rules requiring religious neutrality in the employees' dress code. This situation would mean very different experiences for, say, a Muslim man or a Christian woman. Albeit presented as 'neutral', this measure would disproportionately affect Muslim women who consider the headscarf as a religious requirement, compared with employees whose religious commitment is not expressed through their garments. ${ }^{4}$ Ignoring the intersections of religion, gender and race and how they shape particular situations could thus result in the invisibility of the specific prejudice experienced by Muslim women. Hence, the choice of grounds and comparisons in assessing multiple discrimination is important, as it can either conceal or reveal disadvantage.

With a view to protecting substantive equality, addressing multiple discrimination in EU law is important because it is a widespread problem. The 2015 Eurobarometer on discrimination in the EU revealed that around one-fourth of all discrimination experienced by respondents are of a multiple nature. ${ }^{5}$ This share is even higher among the minority groups of a population. The respondents of a survey conducted by the Fundamental Rights Agency in 2008 and focused on ethnic minorities and immigrants indicated that around $38 \%$ of experiences of discrimination pertained to multiple grounds. ${ }^{6}$ Some scholars even argue that multi-dimensional discrimination should be seen as the norm rather than the exception. ${ }^{7}$ As German constitutional Judge Susanne Baer puts it, the 'social divisions [at the roots of inequality] are multidimensional, complicated and affected by intersectional identities'. ${ }^{8}$ Every individual is, in fact, embedded into a complex network of social memberships and identity groups, which potentially cumulates disadvantage. Hence, inequality is a complex

\footnotetext{
3 See, eg A Vakulenko, 'Islamic Headscarves' and the European Convention on Human Rights: An Intersectional Perspective’ (2016) 16 Social \& Legal Studies 2.

${ }^{4}$ This was precisely the subject of CJEU's decisions C-157/15 Samira Achbita and Centrum voor gelijkheid van kansen en voor racismebestrijding v G4S Secure Solutions NV EU:C:2017:203 and C-188/15 Asma Bougnaoui and Association de défense des droits de l'homme (ADDH) v Micropole SA EU:C:2017:204.

${ }^{5}$ European Commission, Special Eurobarometer 437: Discrimination in the EU in 2015 (European Union, 2015) 8.

6 Calculation based on data from EU Fundamental Rights Agency, 'Data in Focus Report Multiple Discrimination’ EU-MIDIS: European Union Minorities and Discrimination Survey (2010) 4, 10.

${ }^{7} \mathrm{~S}$ Elsuni and AL Göttsche, 'Multidimensional Discrimination and the Law: Views and Experiences from a German Perspective' (2016) Sociologia del Diritto 2.

${ }^{8}$ S Baer, 'Speaking Law: Towards a Nuanced Analysis of "Cases"” (2017) 18 German Law Journal 281.
} 
and multi-layered phenomenon. Grounds of discrimination cannot be understood in isolation from this broader social context.

In 2000, recitals (14) and (3) of the Race Equality Directive (RED) and the Framework Equality Directive (FED) recognised for the first time the problem posed by multiple discrimination stating 'especially [...] women are often the victims of multiple discrimination'. ${ }^{9}$ However, so far, no legislative reform has clarified the definition and place of 'multiple discrimination' in EU anti-discrimination law, despite ongoing discussions in the Council. Even though recent engagement with intersectionality theory at the Court of Justice of the European Union (CJEU) also shows awareness of the specific issues posed by certain forms of multiple discrimination, no fully fledged jurisprudential clarification seems to be forthcoming. ${ }^{10}$ Acknowledging this shortcoming, the GendeRace project, the largest empirical research on multiple discrimination conducted so far in the EU, called for '[a] specific legal methodological framework'. ${ }^{11}$ The gaps of EU anti-discrimination law with regard to the pervasive problem of multiple discrimination raise broader questions about the role of the EU as a promoter of equality.

This chapter, therefore, unpacks the degree of engagement of EU law with the problem of multiple discrimination. To this end, it investigates the issue of multiple discrimination in the EU from three angles. The first shows how scholars and activists in the EU mainly framed multiple discrimination as a feminist issue and how this shaped EU law, prevailing over a transversal understanding pertaining to the whole range of protected grounds. The second reviews how multiple discrimination served as a rationale justifying the multi-ground approach that transformed EU anti-discrimination law in 2000. This section uncovers the gaps between legislation and policy and analyses the ongoing discussions of legal reform. Finally, the third takes a closer look at the CJEU jurisprudence and reveals some sensibility for the concerns raised by intersectionality theory, despite the absence of a targeted doctrinal framework to address claims of multiple discrimination. Throughout these three sections, it is shown that even though the legal framework addressing multiple discrimination in the EU is

\footnotetext{
${ }^{9}$ Council Directive 2000/43/EC implementing the principle of equal treatment between persons irrespective of racial or ethnic origin [2000] OJ L180/22 (Race Equality Directive); Council Directive 2000/78/EC establishing a general framework for equal treatment in employment and occupation [2000] OJ L303/16 (Framework Equality Directive).

${ }^{10}$ Case C-443/15 David L Parris v Trinity College Dublin and Others EU:C:2016:897, Opinion of AG Kokott, paras 149-151.

${ }^{11}$ I Carles and O Jubany-Baucells, GendeRace. The Use of Racial Antidiscrimination Laws: Gender and Citizenship in a Multicultural Context (2010) 270-271. Available at:

http://genderace.ulb.ac.be/rapports/GENDERACE\%20FINAL\%20REPORT\%20sent.pdf.
} 
at best patchy, awareness of the problem has increased since the anti-discrimination reforms in 2000 and growing discussions invoke the need for a legal remedy.

\section{The Emergence of the Issue of Multiple Discrimination in the EU}

Historically, only nationality and sex were protected under EU equality law. ${ }^{12}$ In 1997 , however, Article 13 TEC (now Article 19 TFEU) enabled the adoption of a multi-ground framework. The multiplication of protected grounds from two to seven constituted a window of opportunity to raise public awareness about the issue of multiple discrimination. ${ }^{13}$ Tracing these debates shows how the problem gained attention at institutional level, how it was understood and thus what demands it generated vis-à-vis EU law.

\section{1) Global and European Developments of Intersectionality Theory}

To understand how awareness of the issue of multiple discrimination emerged in the EU, we need to turn to the roots of the debate. From the end of the 1960s throughout the 1970s and the 1980s, feminists of colour in the US denounced the co-production of inequality and exclusion through several distinctive but interdependent social axes of power. Most prominently, they highlighted the double jeopardy caused by racism and patriarchy, but also classism, heteronormativity, imperialism and colonialism. ${ }^{14}$ At the end of the $1980 \mathrm{~s}$, Crenshaw and Hill Collins' foundational pieces theorised the 'interlocking systems of oppression' and the 'matrix of domination' ensuing from the simultaneous membership in multiple marginalised social groups. Since then, a large spectrum of critical scholarship has blossomed under the unifying banner of 'intersectionality theory'. ${ }^{15}$

The concerns conveyed by intersectionality theorists and black feminists subsequently gained visibility in women's and human rights international fora, mainly framed as 'women's

\footnotetext{
12 Art 18 TFEU (ex-Art 12 TEC) and Art 157 TFEU (ex-Art 141 TEC), originally Art 7 and Art 119 of the EEC Treaty.

${ }^{13}$ The anti-discrimination directives currently protect sex, racial and ethnic origin, religion or belief, disability, sexual orientation and age and nationality remains protected by the Treaty.

${ }^{14}$ See P Hill Collins and S Bilge, Intersectionality (Cambridge, Polity Press, 2016) 63-113 and A-M Hancock, Intersectionality: An Intellectual History (New York, Oxford University Press, 2016) 37-71.

${ }^{15}$ Hill Collins and Bilge (n 14) 77, 221-238. See Crenshaw (n 2) (1989), (1991); P Hill Collins, Black Feminist Thought: Knowledge, Consciousness and the Politics of Empowerment (Boston, Hyman, 1990). Throughout this piece I use 'intersectionality theory' as a label encompassing a large spectrum of scholarship that has either used the specific label 'intersectionality' or has developed similar theories.
} 
issues'. ${ }^{16}$ With the Fourth World Conference on Women in 1995 and the ensuing Beijing Declaration, the question of multiple discrimination against women emerged as a pressing issue. ${ }^{17}$ As illustrated by the discussions at the UN World Conference on Racism held in Durban in 2001 and during its preparation phase, ${ }^{18}$ ' $[\mathrm{t}]$ he year 2000 marked an important milestone for the global dispersal of intersectionality'. ${ }^{19}$ By 2000 , intersectionality theory was both internationalised and institutionalised in the 'international diplomacy and human rights governance'. ${ }^{20}$ As the discussion below shows, no unified terminology prevailed in this context. The terms 'intersectional discrimination', 'some other terms captur[ing] its essence' and the concept of 'multiple discrimination' have often been used interchangeably. ${ }^{21}$

In the mid-1990s, as the EU's mandate progressively expanded to include the defence of fundamental rights in the context of the Treaty of Amsterdam and the EU Charter of Fundamental Rights (CFR), ${ }^{22}$ debates about multiple discrimination found an echo in the EU's preoccupation with equality. As the next sections show, some equality advocates, scholars and institutions saw in the preparation of the new anti-discrimination directives a window of opportunity to tackle multi-dimensional forms of discrimination. While 'intersectionality' is the label under which the issue made its way into legal debates in the US, the term 'multiple discrimination' prevailed in EU law, following the pattern sketched by international discussions. EU institutional debates did not refer to intersectionality until recently and legislation only makes mention of 'multiple discrimination' ${ }^{23}$ However, while the term 'multiple discrimination' remains the only one anchored in EU law, a recent

\footnotetext{
${ }^{16}$ Hancock (n 14) 66.

17 'Beijing Declaration and Platform for Action', United Nations Fourth World Conference on Women (15 September 1995) UN Doc A/CONF.177/20, para 32.

${ }^{18}$ Crenshaw was, for instance, invited to the first UN preparatory committee on gender and racial discrimination in 2000 to present a position paper on intersectional discrimination. See K Crenshaw, 'Gender-related aspects of race discrimination' (2000) UN Doc EGM/GRD/2000/WP.1.

${ }^{19}$ Hill Collins and Bilge (n 14) 88, 91.

${ }^{20}$ ibid. See, eg UN Committee on the Elimination of Racial Discrimination, 'General recommendation 25 on gender-related dimensions of racial discrimination' (12 May 2003) UN Doc HRI GEN $\backslash 1 \backslash$ Rev.6; UNCEDAW, 'General Recommendation No 28 on the Core Obligations of States Parties under Article 2 of the Convention on the Elimination of All Forms of Discrimination against Women' (19 October 2010) UN Doc CEDAW/C/2010/47/GC.2.

${ }^{21}$ Hill Collins and Bilge (n 14) 90.

${ }^{22}$ Charter of Fundamental Rights of the European Union [2016] OJ L202/2 (CFR).

${ }^{23}$ One of the first reports commissioned by the European Commission on the topic articulates the link between multiple discrimination and 'the intersectional methodological approach' and 'analysis' needed to deal with it. See European Commission, Tackling Multiple Discrimination: Practices, Policies and Laws (Copenhagen, Danish Institute for Human Rights, 2007) 17.
} 
linguistic shift towards the intersectionality lexicon can be observed both at international and European level. ${ }^{24}$

\section{2) Terminological Controversies: A Lexical Battlefield}

Controversies have arisen because of this terminological inconsistency. For instance, AG Kokott describes the term 'multiple discrimination' as 'misleading as it suggests the presence of two differences of treatment each of which would in its own right - completely independently of the other - have to be regarded as discrimination and would at most be aggravated by the existence of further grounds for a difference of treatment'. ${ }^{25}$ A majority of scholars seems to understand multiple discrimination as an umbrella term covering intersectional but also other multidimensional forms of discrimination, such as 'sequential', 'compound' or 'additive' discrimination. ${ }^{26}$ By contrast, other commentators claim that multiple discrimination is distinct from, and does not encompass, intersectional discrimination. $^{27}$

The label 'intersectional' characterises instances of discrimination that are produced by the synergies of co-constitutive status-based systems of disadvantage. ${ }^{28}$ Conversely, the words 'sequential' and 'additive' or 'compound' have been said to refer to situations in which

\footnotetext{
${ }^{24}$ From 2007 onwards, more and more institutional research has used the term 'intersectionality'. See, eg European Commission, Green Paper on Equality and Non-Discrimination in an Enlarged European Union COM (2004) 379 final; European Commission (2007) (n 23); M Verloo, 'Multiple Inequalities, Intersectionality and the European Union' (2006) 13 European Journal of Women's Studies 211; S Burri and D Schiek, Multiple Discrimination in EU Law: Opportunities for Legal Responses to Intersectional Gender Discrimination? (Brussels, European Commission, 2009); A Lawson and D Schiek (eds), EU Non-Discrimination Law and Intersectionality (Farnham, Ashgate Publishing, 2011); L Rolandsen Agustín (ed) Gender Equality, Intersectionality, and Diversity in Europe (New York, Palgrave Macmillan, 2013); S Fredman, Intersectional Discrimination in EU Gender Equality and Non-discrimination Law (Luxembourg, European Commission, 2016); N Crowley, Innovating at the Intersections: Equality Bodies Tackling Intersectional Discrimination (Brussels, Equinet, 2016); S Carrera et al (ed), Towards a Comprehensive EU Protection System for Minorities (Brussels, European Union, 2017). See also the linguistic evolution at UN level, from CEDAW 20014 general recommendation 25 tackling 'multiple discrimination' and 2010 general recommendation 28 on 'intersectionality' six years later (n 20).

${ }^{25}$ Case C-443/15 Parris (AG Opinion) (n 10).

${ }^{26}$ See, eg M Bell, Racism and Equality in the European Union (Oxford, Oxford University Press, 2009) 21-22; Fredman (n 24) 27-28; D Schiek, 'From EU Non-Discrimination Law towards Multidimensional Equality Law for Europe' in D Schiek and V Chege (eds), European Union Non-discrimination Law: Comparative Perspectives on Multidimensional Equality Law (London, Routledge-Cavendish, 2009); R Nielsen, 'Is EU Equality Law Capable of Addressing Multiple and Intersectional Discrimination Yet?' in ibid; I Solanke, 'Putting Race and Gender Together: A New Approach to Intersectionality' (2009) 72 Modern Law Review 723, 727-728.

${ }^{27}$ T Makkonen, Multiple, Compound and Intersectional Discrimination: Bringing the Experiences of the Most Marginalized to the Fore (Turku, Institute For Human Rights, Äbo Akademi University, 2002) 10-11.

${ }^{28}$ See Solanke (2017) (n 2) 133-159.
} 
multiple grounds are involved in distinct instances of discrimination that can be assessed separately. ${ }^{29}$ Concretely, sequential discrimination corresponds to situations where several occurrences of discrimination take place at different times based on different grounds. ${ }^{30} \mathrm{An}$ example would be the case of an older worker being first harassed in his workplace based on racist motives, and later on discriminated against based on ageist stereotypes, leading to his being refused a promotion. Additive discrimination is said to refer to situations in which discrimination is produced through independent motives related to different grounds but in the same instance. ${ }^{31}$ For example, if a job seeker is denied employment both because the firm applies a said 'neutral' clothing policy that prohibits the wearing of Islamic headscarves at work and refuses to reasonably accommodate her wheelchair, this could be described as additive discrimination.

Perhaps most importantly, the term 'intersectionality' refers to a particular history, intellectual heritage and context of emergence. By using the language of intersectionality, one must acknowledge its anchoring within black feminism and critical race studies, its function as a response to the US civil rights movement and its reference to the total oppression of black women in the context of slavery. Debates have emerged in this regard about the depoliticisation and 'whitening' of intersectionality discussions. ${ }^{32}$ By contrast, the term multiple discrimination emerged in a more international and institutional context. Some commentators have suggested that the conversation in the EU developed around the latter notion because it provides the most 'neutral' and 'overarching' terminology. ${ }^{33}$ Nevertheless, discussing multiple discrimination necessarily takes place within the frame set by intersectionality scholarship.

The commonality of these two concepts lies in the question at the core of the present chapter: what challenge do they pose to EU law? How to assess a claim in which the grounds invoked are inseparably involved in the production of discrimination? This question arises because EU anti-discrimination law and doctrine have been described as 'single-axis' systems, in which claims of discrimination are only investigated on the basis of a single ground at a time, thus

\footnotetext{
${ }^{29}$ See Fredman (n 24); Burri and Schiek (n 24); Makkonen (n 27).

${ }^{30}$ See Fredman (n 24) 27-28.

${ }^{31}$ See Burri and Schiek (n 24).

32 S Bilge, 'Le Banchiment de I'Intersectionnalité' (2015) 28 Recherches féministes 2; I Solanke, 'Intersectionality in the UK: Between the American Paradigm and the European Paradox' (2016) Sociologia del Diritto 2.

${ }^{33}$ Burri and Schiek (n 24) 4. It also presented the advantage of being a global reference, following its earlier endorsement by the UN (n 19).
} 
missing their synergies. ${ }^{34}$ Thus, only those discriminations that involve synergies of statusbased structures of disadvantage actually challenge this system. Additive and sequential discrimination can be dealt with by the prevailing single-axis framework. By contrast, intersectionality theorists underline the need to 'addres[s] inequalities at a structural level and explor[e] the dynamics between [them...], recognising that the experiences of individuals cannot be fully appreciated by separating the oppressions they are subject to'. ${ }^{35}$ Thus, the single-axis framework prevailing in EU law is not appropriate where grounds cannot be disentangled in their co-constitutive dynamics of inequality production.

Despite these clarifications, the relationship between multiple discrimination and intersectionality remains inconsistently - sometimes even contradictorily - accounted for, and the terminology varies among authors. This chapter does not aspire to settle a decades-long debate about the degree of overlap and difference between intersectional and multiple discrimination. Rather, by laying out the terminological indeterminacy and controversy, it shows how language crystallises power relations and embodies knowledge politics. To do justice to the language enshrined in EU law, the term multiple discrimination is used throughout this chapter. However, this chapter also reflects the existing lexicological inconsistency across regulatory fields, institutions, social entrepreneurs and scholarly authorities in the EU, as well as the recent linguistic shift from 'multiple' to 'intersectional' discrimination observable since the beginning of the $2010 \mathrm{~s}$.

The next section refines the understanding of the issue of multiple discrimination in the EU context by investigating the emergence, mobilisations and usages of the notion. Shedding light on the actors that pushed for the recognition of multiple discrimination in EU law, their interests and their agenda ultimately uncovers the meaning they intended to give to the term as well as the legal effect they expected from its introduction into EU legislation.

3) Strategic Mobilisations of the Multiple Discrimination Issue: A Predominantly Feminist Agenda

The meaning of multiple discrimination in the EU has been deeply affected by its context of mobilisation and the history of the construction of EU anti-discrimination law, that have both

\footnotetext{
${ }^{34}$ See Fredman (n 24) 30; (n 26).

${ }^{35}$ A Bach, L Barrington-Leach and R Minto (eds), 'Protecting All Women from Discrimination: Steps to Take at European and National Level’ (Brussels, European Women’s Lobby, February 2010), 32.
} 
featured gender equality as a political priority. Since gender equality has been already protected from discrimination since the Rome Treaty in 1957, feminist activists in the EU were in a privileged position to influence the content of the legal reform broadening the EU equality protection system. The progressive development of anti-racist advocacy movements at national and transnational level and their demands for legislative reforms to combat racism in the EU from the 1990s onwards, notably through the Starting Line, contributed to the emergence of the issue of multiple discrimination on the feminist agenda. ${ }^{36}$

From the end of the 1980s and the beginning of the 1990s onwards, a number of feminist groups at national level became concerned by the rise of xenophobia and racism in the EU, and by the lack of voice given to migrant and ethnic minority women. ${ }^{37}$ In 1995, a report drafted by the European Forum of Socialist-Feminists (EFSF), commissioned by the European Women's Lobby (EWL) and published by the European Parliament notably addressed 'the multiple ways in which black and migrant women are discriminated against in the labour market, in immigration processes and as a result of racism' ${ }^{38}$ In warning that '[i]f nothing is done to counter this, the development of the Single Market is likely only to enhance this disadvantage', EFSF was already pointing at the gaps in EU law with regard to the problem of multiple discrimination based on sex and race. ${ }^{39}$ This brief historical account reveals that early conceptualisations of the multiple discrimination problem were mainly channelled onto the EU policy and legislative agenda through feminist groups. From the outset, the question of multiple discrimination was thus posed, both in international fora and at EU level, from the angle of women's rights.

Multiple discrimination was also on the agenda of advocacy groups engaged in anti-racist legislative lobbing from the 1980 s to 2000 , albeit in implicit terms. In fact, they had initially pushed for a directive prohibiting discrimination both on the basis of race and religion, to

\footnotetext{
${ }^{36}$ See, eg I Chopin and J Niessen, Proposals for Legislative Measures to Combat Racism and Promote Equal Rights in the European Union (London, Commission for Racial Equality, 1998).

${ }^{37}$ See A Subhan, Confronting the Fortress: Black and Migrant Women in the European Union (Brussels, European Parliament, 1995); S Lees and M McIntosh, 'European Forum of Socialist-Feminists' (1986) 23 Feminist Review 139; J Patel, Overcoming Discrimination: Selected Strategies Empowering Black, Ethnic Minority and Migrant Women (European Women's Lobby, 1999). Available at: www.womenlobby.org/Overcoming-Discrimination-Selected-Strategies-Empowering-Black-EthnicMinority?lang=en 5, 21, 23; European Women's Lobby, EWL Position Paper on integration a gender dimension in the proposed measures to implement the anti-discrimination clause (art. 13 of the EC Treaty) (August 2000). Available at: www.womenlobby.org/-Position-Papers-

?lang=en\&debut_rubrique_articles=10\#pagination_rubrique_articles.

${ }^{38}$ Subhan (n 37) $\overline{2} 5$.

39 ibid.
} 
tackle the dangers posed by the racialisation of certain religious groups in Europe. ${ }^{40}$ However, the two issues were finally separated in the 2000 Directives (RED and FED). Hence, the multiple discrimination problem materialised on the EU agenda as a feminist issue.

At the legislative level, this women's rights based understanding of multiple discrimination shows in the framing of the issue. The EU is under a duty to promote gender equality, 'especially since women are often the victims of multiple discrimination'. ${ }^{41}$ This formulation reflects the legislative lobbying of feminist advocacy groups like EWL on the Commission and the Parliament. Gender activists in fact had a double interest in bringing the issue of multiple discrimination to the fore.

First, they aimed to avoid a dilution of the resources dedicated by the EU to antidiscrimination policies across the new spectrum of protected grounds, and to ensure the continuity of the political attention granted to feminist issues. ${ }^{42}$ The publicity given to the issue of multiple discrimination against women was therefore a strategic way to uphold the protection of gender equality as a priority on the Union's agenda. Indeed, the explanatory memorandum accompanying the FED states that:

Although equal treatment on the grounds of sex is not covered as such by this Directive, it is nevertheless recognised that discrimination on the grounds of either race/ethnic origin, disability, age, religion/belief or sexual orientation may affect women and men differently. The structural inequalities linked to sex and gender roles of women and men are frequently even more important in the context of dual, triple or multiple discrimination [...]. The necessity to apply a gender mainstreaming approach is a logical consequence $[\ldots]^{43}$

In the same vein, the Commission's explanatory memorandum accompanying its proposal for the RED makes the case for 'double discrimination' and the 'mainstreaming' of sex equality into the race equality protection.

EWL framed the 'integration of the principle of gender mainstreaming in the draft directive[s]' as a consequence of the need 'to tackle the issue of double/multiple

\footnotetext{
${ }^{40}$ Chopin and Niessen (n 36)

${ }^{41}$ Recitals (14) and (3) of the Race Equality and the Framework Equality Directives (emphasis added).

${ }^{42}$ G Vara Arribas and L Carrasco, 'Gender Equality and the EU: An Assessment of the Current Issues' (2003) 1 Eipascope 24.

${ }^{43}$ Explanatory memorandum accompanying the Proposal for a Council Directive COM/2008/0426 final on implementing the principle of equal treatment between persons irrespective of religion or belief, disability, age or sexual orientation [2008] C303/8.
} 
discrimination that many women face' ${ }^{44}$ The rationale put forward was that sex discrimination is 'of a particular structural nature' and concerns 'half of the population' ${ }^{45}$ By contrast, multiple discrimination is absent from the directives protecting gender equality, which confirms its primary conceptualisation as a women's rights issue. The downside of this development is that multiple discrimination has not (yet) been defined in EU law as a transversal problem that could lead to other forms of structural discrimination beyond genderplus configurations. ${ }^{46}$

Second, the broadening of the protection against discrimination constituted an opportunity for the advocates of gender equality to build alliances with other groups. Because equality advocacy in Europe is mostly structured around salient social identities (race, sexual orientation, etc.), it often leads to what Crenshaw calls 'political intersectionality', a situation in which identity politics is detrimental to the participation and representation of groups at the intersection of several axes of disadvantage. ${ }^{47}$ Hence, multiple discrimination can be used as a strategic argument to build coalitions across groups, thus bridging ground-based advocacy.

For feminist activists, 'acknowledging multiplicity and intersectionality ha[d] the potential to strengthen the issue of gender equality'. ${ }^{48}$ However, the mobilisation of the multiple discrimination issue as a political mainstreaming strategy and a coalitional tool by feminists partially failed to avoid competition. Cullen explains that tensions arose at the time of the preparation of the 2000 directives because EWL understood multiple discrimination as 'a hierarchical phenomenon defined as different forms of discrimination added to structural discrimination based on sex', putting forward that 'most people disadvantaged by intersectional discrimination are female', a position not necessarily shared by other NGOs. ${ }^{49}$

\footnotetext{
${ }^{44}$ See European Women's Lobby n 37). See also the amendments proposed by the European Parliament, 'Report on the proposal for a Council directive on implementing the principle of equal treatment between persons irrespective of racial or ethnic origin' A5 (2000) 136 final, 16 May 2000 and 'Report on the proposal for a Council directive on the proposal for a Council directive establishing a general framework for equal treatment in employment and occupation' A5 (2000) 264, 21 September 2000.

45 EWL (n 37).

${ }^{46}$ See P Cullen, 'The Platform of European Social NGOs: Ideology, Division and Coalition' (2010) 15 Journal of Political Ideologies 317, 331.

${ }^{47}$ Crenshaw (1991) (n 2).

${ }^{48}$ Burri and Schiek (n 24) 5.

${ }^{49}$ ibid and Cullen (n 46).
} 
At the legislative level, the issue of intersectionality has not yet given rise to a transversal framework applicable to multi-dimensional discrimination across all protected grounds. ${ }^{50}$ This shortcoming could explain why multiple discrimination as a legal concept has not had more bite in EU law so far.

\section{Differentiated Protection against Multiple Discrimination}

The reforms introduced by the 2000 directives anchored the notion of multiple discrimination in EU law. However, its underdevelopment entertains uncertainties and confusion around its meaning, legal relevance, and utility for the fight against discrimination in the EU. The consequence is a gap between the empirically demonstrated problems posed by multiple discrimination and the patchy protection offered by EU law.

\section{1) Legislation: Very Limited Protection}

The attention given to multiple discrimination in EU law is an important, but limited, achievement. Firstly, the discussions about multiple discrimination have not translated into a full prohibitive apparatus. Only enshrined in the recitals (14) and (3) of the RED and FED, this issue is currently not addressed through a binding legal provision. Nonetheless, it has political value as a guideline in making and interpreting EU anti-discrimination law. This lack of directly binding force is paired with a silence on content, as the notion is not defined. The situation raises questions as to the meaning and purpose of this relatively new concept in EU anti-discrimination law that have still not been clarified today.

The Commission, however, highlighted the 'need to tackle', 'defin[e]' and 'provide effective remedies' for multiple discrimination on the occasion of its proposal for a Horizontal Directive in $2008 .{ }^{51}$ Despite these acknowledgments, the Commission ultimately opted for a non-binding provision modelled on the recitals of the RED and FED. ${ }^{52}$

\footnotetext{
${ }^{50}$ However, a recent institutional report on minority rights indicates a re-mobilisation of intersectionality theory to understand the grounds of race, ethnicity, nationality, culture, religion and language as co-constitutive, i.e. 'closely linked and interrelated'. See Carrera et al (n 24).

${ }^{51}$ Proposal for a Council Directive COM/2008/0426 final on implementing the principle of equal treatment between persons irrespective of religion or belief, disability, age or sexual orientation [2008] OJ C303/8. See E Howard, 'The Case for a Considered Hierarchy of Discrimination Grounds in EU Law' (2006) 13 Maastricht Journal of European and Comparative Law 445. The Commission cites expert reports to justify this innovation.

${ }^{52}$ See European Commission, Explanatory Memorandum COM (2008) 426 final.
} 
The Parliament, consulted in the framework of what was originally the consultation procedure, ${ }^{53}$ proposed a systematic prohibition of multiple discrimination through comprehensive amendments, including a transversal definition in Article 1 of the envisaged directive:

1. This Directive lays down a framework for combating discrimination, including multiple discrimination $[\ldots]$.

2. Multiple discrimination occurs when discrimination is based:

(a) on any combination of the grounds of religion or belief, disability, age, or sexual orientation, or

(b) on any one or more of the grounds set out in paragraph 1, and also on the ground of any one or more of

(i) $\operatorname{sex}[\ldots]$,

(ii) racial or ethnic origin $[\ldots]$, or

(iii) nationality[...].

3. In this Directive, multiple discrimination and multiple grounds shall be construed accordingly. ${ }^{54}$

It also proposed to modify recital (13) by amendments 10 and 23 as follows:

This Directive also takes into account multiple discrimination. As discrimination can occur on two or more $[\ldots]$ grounds $[\ldots]$, the Community should $[\ldots]$ promote equality, whatever combination of characteristics $[\ldots]$ a person may have. Effective legal procedures should be available to deal with situations of multiple discrimination. In particular national legal procedures should ensure that a complainant can raise all aspects of a multiple-discrimination claim in a single procedure. ${ }^{55}$

The Parliament also proposed to systematically include multiple discrimination as a concept in its own right, along with indirect and direct discrimination and discrimination by association. ${ }^{56}$

2) Latest Developments: Towards Legislative Clarifications on Multiple Discrimination?

\footnotetext{
53 However, after the Lisbon Treaty came into force, the special legislative procedure for legislation on discrimination followed the consent procedure delineated in Art 289(2) TFEU. The approval of the European Parliament therefore became binding.

54 See European Parliament Legislative Resolution of 2 April 2009 on the Proposal COM(2008)0426, Amendment 37 of the EP, 2009, Art 1.

${ }^{55}$ Amendments 10 and 23 (emphasis added), see (n 54).

${ }^{56}$ See (n 54): amendments 7, 12, 16 on the recitals citing the different existing forms of discrimination and 80 on reporting obligations.
} 
Until recently, the Council had retained none of the Parliament's proposed legislative changes concerning multiple discrimination. ${ }^{57}$ Discussions of the legislative proposal since 2008 have not yielded unanimity so far, curtailing the perspective of an upcoming change. All in all, even though EU civil society, anti-discrimination experts and the European Parliament have pushed for reforms towards a comprehensive framework of protection against multiple discrimination beyond the current gender-plus understanding, these attempts have not been successful. Multiple discrimination thus remains a grey zone, officially depicted as a problematic issue, but still outside of the binding scope of the anti-discrimination directives.

Recent Council discussions on the Commission's 2008 Proposal, held in June 2017, nevertheless point towards a clearer and stronger stance on multiple discrimination. This could potentially translate into a legislative prohibition if the new anti-discrimination directive was adopted, especially because of the Commission's support. A report reveals that the 2017 Maltese presidency aimed to 'clarify the issue of multiple discrimination', recognising that 'discrimination on the grounds covered in the proposal could also intersect with discrimination on the grounds of racial or ethnic origin and nationality, as well as sex or gender identity' ${ }^{58}$ The new text under discussion also understands 'multiple discrimination in general terms instead of singling out a specific combination of grounds' as is currently the case with 'multiple discrimination against women'. Hence, the current women's rights based understanding of the problem of multiple discrimination could evolve towards a more transversal one.

Concretely, recital (12) of the new text clarifies that direct discrimination includes multiple discrimination. ${ }^{59}$ While recital (13) still specifies that 'women are often the victims of multiple discrimination', new recital (12)(ab) acknowledges that '[d]iscrimination on the basis of religion or belief, disability, age or sexual orientation may be compounded by or intersect with discrimination on grounds of sex or gender identity, racial or ethnic origin, and nationality'. ${ }^{60}$ Recital (21) authorises Member States to take positive action measures to

\footnotetext{
${ }^{57}$ See Council, 'Proposal for a Council Directive on implementing the principle of equal treatment between persons irrespective of religion or belief, disability, age or sexual orientation (consolidated text)' ST 14500/16, 14 December 2016.

${ }^{58}$ Council, 'Proposal for a Council Directive on implementing the principle of equal treatment between persons irrespective of religion or belief, disability, age or sexual orientation (consolidated text)' ST 9481/17, 1 June 2017.

59 ibid.

${ }^{60}$ ibid.
} 
support 'group[s] of persons [...] having a combination of characteristics' ${ }^{61}$ The proposal also prohibits multiple discrimination in its binding provisions Articles 2(2)(a) and (b) 'on one or more [...] grounds' and for 'indirect discrimination on one or multiple grounds' ${ }^{62}$ At the definitional level, however, the use of both the terms 'compounded by' and 'intersect' generates confusion as regards the difference between the two terms and the challenges they pose to EU law.

As it stands, the proposal bears witness to a growing awareness of the harms created by multiple discrimination and indicates a willingness to close the legal gap. That said, the Council discussions reveal disagreements as to the place of multiple discrimination in the directive, the grounds covered and the attached sanctions. ${ }^{63}$ More generally, all Member States currently do not support the inclusion of multiple discrimination in the directive. ${ }^{64}$ Hence, the perspective of a full legislative ban is still distant and multiple discrimination remains a grey zone in EU legislation at present.

\section{3) The Policy Path: Recommendations, Enforcement, Monitoring, Funding}

By contrast to fragmentary legislation, intersectionality has been a blossoming concept in policy and academic debates at the EU level. The problem of multiple discrimination has gained visibility through the Commission's efforts to push the EU's equality programme forward, in a time of legitimacy crisis and legislative deadlock, supported by a growing body of research. As a political rhetoric, multiple discrimination has become a rationale for further reform and better enforcement of anti-discrimination law. Diverse policy tools aim to fill the gap between a declared necessity to fight against multiple discrimination and the absence of clear legislative guidelines.

At the political and institutional level, the Commission and national equality bodies and experts have contributed to the production of an important body of research, reports, and programs for action addressing multiple discrimination. ${ }^{65}$ From 2000 onwards, EU institutions

\footnotetext{
61 ibid.

62 ibid.

${ }^{63}$ See Council, 'Proposal for a Council Directive on implementing the principle of equal treatment between persons irrespective of religion or belief, disability, age or sexual orientation (consolidated text)' ST 10779/17, 29 June $2017,9$.

64 ibid at 8.

65 See, eg Council, Decision 2000/750/EC establishing a Community action programme to combat discrimination (2001 to 2006) [2000] OJ L303/23; Council, Decision No 1554/2005/EC establishing a
} 
regularly noted the existence of, and the need to tackle, multiple discrimination. ${ }^{66}$ In 2004 , the Commission stated in a Green Paper that ' $[t]$ he development of an integrated approach [wa]s intended, in particular, to respond to situations of multiple discrimination'. ${ }^{67}$ In 2007 and 2009, two major research reports were financed and published by the European Commission on the topic, followed by more recent reports on 'intersectional discrimination'. ${ }^{68}$

The issue has thus progressively gained relevance in policy discussions and scientific research, despite its limited anchoring in legislation. This is especially visible in the areas of enforcement, monitoring and funding. For example the 'Community action programme to combat discrimination 2001-2006' recommended effective monitoring of multiple discrimination, while the European Year for Equal Opportunities in 2007 promoted a 'balanced treatment of grounds with the focus on multiple discrimination and an obligation to mainstream gender across all activities; ${ }^{69}$ The Commission also dedicated special funding to improve the situation of Roma women as a group facing multiple discrimination. ${ }^{70}$

In practice, the conceptualisation of multiple discrimination in EU policy retains a predominant gender dimension. Even though signs of diversification are visible, a transversal policy strategy to combat all kinds of multiple discrimination has not yet been elaborated. At the same time, the production of a political discussion on intersectional discrimination by the EU Commission might be perceived as part of a new mode of governance aiming to create consensus within the EU political space, and thus encourage reforms at the national level. This form of top-down acculturation could potentially lead to consensus building over time, and to overcoming the current Member State opposition to reform.

programme relating to the Community framework strategy on gender equality [2005] OJ L255/9 and Council, 'Resolution on the situation of persons with disabilities in the European Union' [2008] OJ C75/1; European Parliament, 'Resolution on the situation of women from minority groups in the European Union' 2003/2109(INI), 9 March 2004; European Parliament, 'Resolution on the situation of Roma women in the European Union' 2005/2164(INI), 1 June 2006; Commission, 'Non-discrimination and equal opportunities for all - A framework strategy' COM(2005) 224 final (Brussels, 2005); Commission, 'Strategy for equality between women and men' (2010); Commission, 'Report on the implementation of the UN Convention on the Rights of Persons with Disabilities (CRPD) by the European Union 2010-2015' SWD(2014) 182 final (Brussels, 2014). See also Carles and Jubany-Baucells (n 11); D Schiek and J Mulder, 'Intersectionality in EU Law: a Critical Reappraisal' in Lawson and Schiek (n 22) 27, 3; BG Bello, 'Discriminazione multiple e intersezionalità: queste sconosciute!' (ASGI, 2015). Available at: www.asgi.it/wp-content/uploads/2015/05/Approfondimento-BarbaraGiovanna-Bello_-Maggio-2015.pdf.

${ }^{66}$ See ibid.

${ }^{67}$ European Commission (n 22) 28.

${ }^{68}$ See Crowley (n 24); Fredman (n 24).

69 See Commission, 'Implementation, results and overall assessment of the 2007 European Year of Equal Opportunities for All' COM (2009) 269 final, 19 June 2009. Decision 2000/750/EC (61), recital 5, Art 2 and annex (I)(e).

70 ibid. 
At the discursive level, one observes that the conceptualisation of multiple discrimination shifted over time, translating into a progressive change of linguistic paradigm. Two stages appear in the conversations about multiple discrimination. From debates on a multi-ground equality framework, discussions on multiple discrimination emerged. In a second moment, the term intersectionality surged in recent analyses and progressively competed with framing in terms of multiple discrimination. ${ }^{71}$ This evolution reflects a change in the political demands associated with the notion of multiple discrimination.

Originally serving as a rhetorical keystone giving seeming coherence and unity to a fragmented body of anti-discrimination norms, the discourse on the necessity to combat multiple discrimination was pushed forward as a leitmotiv for a comprehensive equality protection. ${ }^{72}$ Following a similar logic of coherence, the problem of multiple discrimination has also been instrumentalised as a tool of resource management. The majority of Member States have, for instance, re-arranged their anti-discrimination institutions following an integrated approach with single equality bodies or integrated human rights institutions. ${ }^{73}$ This has caused some concern about the redistribution of constant (or shrinking) resources across more grounds, and the dilution of ground-specific expertise along a broader spectrum. ${ }^{74}$ In this first stage, however, the real problems caused by multiple discrimination were not soundly addressed. In 2006, Verloo regretted that 'studies do not use (structural) intersectionality as a concept to help understand the nature of the relationship between different inequalities'.75

In the second stage, the instrumental use of the issue of multiple discrimination as a political leitmotiv gave way to deeper reflections on the problem itself and how it challenges EU law in its current state. For instance, the GendeRace report calls for 'an explicit reference to multiple discrimination as an especially vulnerable form of discrimination within the new European Directive enlarging the scope of protection against discrimination' and '[a]n operational definition of multiple and intersectional discrimination meet[ing] the standards set out in Article 21 [...ECFR...] that could render it possible to offer protection from multiple

\footnotetext{
${ }^{71}$ See (n 22).

72 See Decision 2000/750/EC (n 61).

${ }^{73}$ Art 13 of the RED and Arts 12 and 20 of the Gender Directives 2004/113/EC and 2006/54/EC have rendered compulsory the creation of national equality bodies dealing with assistance to victims, reporting and recommendations in the fields of sex and race equality.

${ }^{74}$ See S Walby, J Armstrong and S Strid, 'Intersectionality and the Quality of the Gender Equality Architecture' (2012) 19 Social Politics: International Studies in Gender, State \& Society 446.

${ }^{75}$ Verloo (n 24) 215.
} 
discrimination'. ${ }^{76}$ Similarly, the Fundamental Rights Agency calls for policies, data collection, equality bodies and complaint procedures that facilitate the identification and treatment of multiple discrimination, as well as for a legislative definition and prohibition. ${ }^{77}$ In parallel, growing academic interest in the field has revived and shifted the debate on multiple discrimination towards intersectionality. ${ }^{78}$ By underlining the specific nature of intersectional discrimination, these discussions seem to push for legislative and doctrinal reforms to improve equality protection beyond the predominant gender-plus understanding of multiple discrimination.

While the solutions offered to the problem of multiple discrimination suffer from a discrepancy between political ambitions and legal means, questions remain as to whether and how the problem could be tackled within the current EU anti-discrimination apparatus. Although a legislative ban would bring much-needed clarity, the references to multiple discrimination in the RED and FED suggest that the problem could be addressed through judicial interpretation. However, so far the Court of Justice has not played its part in addressing intersectional discrimination.

\section{Remedying Multiple Discrimination: Obstacles and Resistance}

Despite its historical role in advancing equality in the early age of the EU, the Court of Justice has not taken the lead on new anti-discrimination innovations to tackle multiple discrimination. Even though similar issues have been brought to the attention of the Court before, the question was only posed explicitly for the first time in 2016. However, to this day, the CJEU has neither proposed a doctrinal framework nor appropriate remedies to deal with multiple discrimination. This deficit is problematic as important strands of inequality risk remaining under the Court's radar. It is especially disconcerting considering the general lack of minimum standards dealing with intersectional discrimination in Member States. The absence of explicit jurisprudential guidelines to recognise and remedy multiple discrimination thus contributes to the invisibility of the harms it causes.

\section{1) Obstacles to the Recognition of Multiple Discrimination}

\footnotetext{
${ }^{76}$ Carles and Jubany-Baucells (n 10) 270-271.

${ }^{77}$ EU-MIDIS, 17. See (n 6).

78 See Schiek and Chege (n 24); Lawson and Schiek (n 11). See also Carles and Jubany-Baucells (n 10); Fredman (n 22).
} 
The barriers preventing the doctrinal recognition of synergistic discrimination based on multiple grounds are numerous and diverse. Firstly, the absence of an explicit and binding prohibition of multiple discrimination in EU legislation is problematic. It does not provide the Court with a clear mandate in redressing complex forms of inequality or in conducting combined analyses of discrimination. ${ }^{79}$ However, national examples show that multiple discrimination has been recognised through judicial interpretation in jurisdictions which did not necessarily have a specific legislative provision. ${ }^{80}$

Secondly, the current legislative architecture encourages a fragmented approach. The antidiscrimination apparatus, composed of different legislative instruments, the Treaties and the ECFR, apply different regimes of exceptions, justifications, remedies and scopes of application ratione materiae to different grounds. This poses questions about the relevant legal regime and standard of review in case of multiple discrimination. Hence, the harmonisation of the material scopes of the different directives through a Horizontal Directive would be an important step towards the facilitation of an integrated approach to multiple discrimination.

Thirdly, even though nothing prevents applicants from bringing claims of multiple discrimination to the Court of Justice, the complexities highlighted above contribute to deter them. It encourages litigators to strategically select the most 'intuitive' (or perhaps 'favourable') ground, thus limiting access to justice for the victims of multiple discrimination.

The prevailing single-ground approach is a fourth obstacle to efficient redress because it heightens the evidence threshold by requiring proof for each ground taken in isolation, which is at odds with the reality of co-constitutive forms of multiple discrimination. This links to the difficulties of selecting appropriate comparators for multiple discrimination cases: ${ }^{81}$ should the comparator be someone who shares one, all or none of the characteristics claimed? To render situations of intersectional discrimination visible, the comparison should arguably be made with the most privileged individual in all concerned groups, be it real or hypothetical. ${ }^{82}$

\footnotetext{
79 See Case C-443/15 Parris EU:C:2016:897.

${ }^{80}$ Eight EU Member States have references to multiple discrimination in their legislation. See Fredman (n 22) 51.

${ }^{81}$ See S Goldberg, 'Discrimination by Comparison' (2011) 120 Yale Law Journal 690; M Kotkin, 'Diversity and Discrimination: A Look at Complex Bias' (2009) 50 William and Mary Law Review 1439.

${ }^{82}$ See UK Equality Act 2010 and its pending provision on double discrimination, which recommends comparing with the most privileged categories.
} 
However, even such inclusive comparisons often lead to truncated visions of the reality of inequality. ${ }^{83}$

Because 'inequalities are not independent' but rather the product of 'many historical, political, social and cultural intersections', ${ }^{84}$ a contextual and situated analysis informed by an interdisciplinary methodology relying on social science could better inform the analyses of discrimination by courts. ${ }^{85}$ As some pregnancy discrimination case law proves, the Court of Justice punctually abandoned the comparator-based framework in favour of a more contextual analysis. ${ }^{86}$ A victim's perspective approach focusing on harmful effects - as already used in cases of harassment and stereotyping in the US - as opposed to a perpetrator's perspective focusing on differential treatment and the use of grounds as 'vehicles' to think about stigmatisation and disadvantage would certainly lead to better recognition of co-constitutive forms of multiple discrimination. ${ }^{87}$ As Kotkin puts it, 'nothing in discrimination law doctrine [...] necessarily prevents some expansion of the evidentiary pool in this manner' ${ }^{88}$ However, courts in general, and the CJEU in particular, are reluctant to abandon the comparator-based test, probably because of the scientific appearance and the colour of neutrality it confers to anti-discrimination analysis. ${ }^{89}$

Despite this reticence, landmark cases like Roca Alvarez (2010), ${ }^{90}$ Coleman (2008), ${ }^{91}$ and CHEZ (2015) $)^{92}$ show that the Court's jurisprudence can prove well informed by assessments of social power relations, stereotyping and inequality structures. Therefore, this kind of contextual analysis already developed in some other fields of the Court's equality

\footnotetext{
${ }^{83}$ See Goldberg; Kotkin (n 81).

84 Verloo (n 24) 222.

${ }^{85}$ Canadian courts have acknowledged this necessity: 'In Canada, as the understanding of human rights evolves, the focus is increasingly on a contextualized approach to discrimination' in Ontario Human Rights Commission, 'An intersectional approach to discrimination: Addressing multiple grounds in human rights claims' (2001). See also the socio-legal framework proposed in I Solanke, 'A method for intersectional discrimination in EU Labour Law' in A Bogg, C Costello and ACL Davies (eds), Research Handbook of European Labour Law (Cheltenham, Edward Elgar Publishing, 2016).

${ }^{86}$ See Case C-177/88 Elisabeth Johanna Pacifica Dekker v Stichting Vormingscentrum voor Jong Volwassenen (VJV-Centrum) Plus EU:C:1990:383.

${ }^{87}$ See Justice L'Heureux Dubé's dissent in Egan v Canada, [1995] 2 SCR 513 and Price Waterhouse v Hopkins, 490 US 228 (1989), 109 S Ct 1775. On the perspective discussion, see AD Freeman, 'Legitimizing Racial Discrimination through Antidiscrimination Law: A Critical Review of Supreme Court Doctrine' (1978) 62 Minnesota Law Review 1049. On stereotyping, see A Timmer, 'Judging Stereotypes: What the European Court of Human Rights Can Borrow from American and Canadian Equal Protection Law' (2015) 63 The American Journal of Comparative Law 239.

${ }^{88}$ Kotkin (n 81).

${ }^{89}$ See Goldberg (n 81) 728.

${ }^{90}$ Case C-104/09 Pedro Manuel Roca Álvarez v Sesa Start España ETT SA EU:C:2010:561.

${ }^{91}$ Case C-303/06 S Coleman v Attridge Law and Steve Law EU:C:2008:415.

${ }^{92}$ Case C-83/14 CHEZ Razpredelenie Bulgaria AD contre Komisia za zashtita ot diskriminatsia EU:C:2015:480.
} 
jurisprudence could be a useful complement to the hypothetical comparators already in use. However, it poses questions pertaining to resources and expertise, where national equality bodies could play an important role.

These obstacles make the recognition of co-constitutive forms of multiple discrimination difficult, yet the next section shows that the CJEU has more and more explicitly grappled with the problem of multiple discrimination in recent times.

\section{2) Multiple Discrimination at the CJEU: An Issue Too Long Overlooked}

So far, preliminary references have not given the Court many occasions to become aware of the magnitude of the issue of multiple discrimination. Besides, even when judges have been exposed to this reality, a single-ground approach has mostly prevailed. Nonetheless, some signs in the CJEU discrimination jurisprudence show sensibilities for the problem of complex inequality and co-constitutive discrimination, even where the language of multiple discrimination is absent.

\section{a. Overview of the Cases brought on Multiple Grounds}

The table below tracks all cases so-far decided by the CJEU in which claims of discrimination invoking multiple grounds have been put forward. ${ }^{93}$ It helps in understanding how multiple discrimination claims reach the CJEU and how they are dealt with by the Court.

\footnotetext{
${ }^{93}$ Last updated in March 2017. The present analysis only considers cases that have explicitly invoked multiple grounds but some cases that have been brought under a sole protected ground could be considered multiple discrimination cases. See for instance the analysis in J Fudge and A Zbyszewska, 'An Intersectional Approach to Age Discrimination in the European Union: Bridging Dignity and Distribution?' in A Numhauser-Henning and M Rönnmar (eds), Age Discrimination and Labour Law: Comparative and Conceptual Perspectives in the EU and Beyond (Alphen aan den Rijn, Kluwer, 2015).
} 


\begin{tabular}{|c|c|c|c|}
\hline CASE & $\begin{array}{l}\text { GROUNDS } \\
\text { CLAIMED }\end{array}$ & TYPE OF CLAIM & DECISION \\
\hline $\begin{array}{l}\text { C-227/04 P Maria-Luise Lindorfer v. Council } \\
\text { of the European Union EU:C:2007:490, } \\
\text { [2007] ECR I-6767 } \\
\text { (Appeal following decision T-204/01 (2004) } \\
\text { of the General Court) } \\
\text { Facts: An EU worker claims that the use of } \\
\text { gender-based actuarial factors in the } \\
\text { calculation of her pension benefits and their } \\
\text { conversion in national currency puts her at a } \\
\text { disadvantage. }\end{array}$ & $\begin{array}{l}\text { - } \text { Sex } \\
\text { - Age } \\
\text { - Nationality }\end{array}$ & $\begin{array}{l}\text { Combined claim of breach of } \\
\text { the principle of equal } \\
\text { treatment based on age and } \\
\text { sex (T-204/01, [44]) } \\
\text { Separate claim of } \\
\text { discrimination based on } \\
\text { nationality (T-204/01, [39]) }\end{array}$ & $\begin{array}{l}\text { Separate } \\
\text { examination: } \\
\text { discrimination } \\
\text { based on sex but no } \\
\text { discrimination } \\
\text { based on age; } \\
\text { nationality-based } \\
\text { claim dismissed }\end{array}$ \\
\hline $\begin{array}{l}\text { C-356/09 Pensionsversicherungsanstalt v } \\
\text { Christine Kleist EU:C:2010:703, [2010] ECR } \\
\text { I-11939 } \\
\text { Facts: the company employing Ms. Kleist } \\
\text { decided to terminate the contracts of all } \\
\text { employees satisfying the conditions for } \\
\text { retirement. The age requirement was } 60 \text { for } \\
\text { women and later for men. Ms. Kleist wished to } \\
\text { continue working and claimed age and sex } \\
\text { discrimination. }\end{array}$ & $\begin{array}{l}\text { - Sex } \\
\text { - Age (only in } \\
\text { Kleist's } \\
\text { submitted } \\
\text { observations, } \\
\text { not in the } \\
\text { preliminary } \\
\text { reference } \\
\text { questions) }\end{array}$ & $\begin{array}{l}\text { Question only based on } \\
\text { - Sex: Article 3(1)(c) of } \\
\quad \text { Directive } 76 / 207 \\
\text { NB: in the preliminary } \\
\text { reference, there was no } \\
\text { question regarding age } \\
\text { discrimination, and thus the } \\
\text { CJEU does not examine } \\
\text { Directive 2000/78/EC. } \\
\text { However, the applicant } \\
\text { claims both sex and age } \\
\text { discrimination based on both } \\
\text { directives. The CJEU only } \\
\text { examines sex discrimination } \\
\text { but age enters into the } \\
\text { analysis through the question } \\
\text { of pension rules. }\end{array}$ & $\begin{array}{l}\text { Single-ground } \\
\text { examination: } \\
\text { - Direct } \\
\text { discrimination } \\
\text { based on sex } \\
\text { - No question } \\
\text { about age } \\
\text { discrimination, } \\
\text { hence no } \\
\text { finding on this } \\
\text { issue. }\end{array}$ \\
\hline $\begin{array}{l}\text { C-310/10 Ministerul Justiţiei și Libertăţilor } \\
\text { Cetăteneşti v Ştefan Agafitei and Others } \\
\text { EU:C:2011:467, [2011] ECR I-05989 } \\
\text { Facts: Romanian judges claim discrimination } \\
\text { as regards pay, based on social class or socio- } \\
\text { professional membership and place of work. }\end{array}$ & $\begin{array}{l}\text { - Place of work } \\
\text { (not protected } \\
\text { under EU } \\
\text { law) } \\
\text { - Membership } \\
\text { in a socio- } \\
\text { professional } \\
\text { category (not } \\
\text { protected } \\
\text { under EU } \\
\text { law) }\end{array}$ & $\begin{array}{l}\text { Combined question based on } \\
\text { Article } 15 \text { of Council } \\
\text { Directive } 2000 / 43 \\
\text { Article } 17 \text { of Council } \\
\text { Directive } 2000 / 78\end{array}$ & $\begin{array}{l}\text { Inadmissibility of } \\
\text { the preliminary } \\
\text { reference: the } \\
\text { grounds cited are } \\
\text { not protected under } \\
\text { the directives } \\
2000 / 43 / \mathrm{EC} \text { and } \\
2000 / 78 / \mathrm{EC}\end{array}$ \\
\hline
\end{tabular}




\begin{tabular}{|c|c|c|c|}
\hline $\begin{array}{l}\text { C-415/10 Galina Meister } v \text { Speech Design } \\
\text { Carrier Systems GmbH EU:C:2012:217 } \\
\text { [2012] } \\
\text { Facts: after her application to an advertised job } \\
\text { position has been dismissed twice without her } \\
\text { being invited to an interview although her } \\
\text { profile corresponded the job description, Ms. } \\
\text { Meister is refused information as regards her } \\
\text { rejection by the employer. She claims } \\
\text { discrimination based on sex, ethnic origin and } \\
\text { age. }\end{array}$ & $\begin{array}{l}\text { - Sex } \\
\text { - Ethnic origin } \\
\text { - Age }\end{array}$ & $\begin{array}{l}\text { Combined question based on } \\
\text { - Sex: Article } 19(1) \text { of } \\
\text { Directive } 2006 / 54 \\
\text { Ethnic origin: } \\
\text { Article } 8(1) \text { of Directive } \\
\text { 2000/43 } \\
\text { Age: Article } 10(1) \text { of } \\
\text { Directive } 2000 / 78 \\
\text { (NB: the } 3 \text { articles claimed } \\
\text { cover the exact same } \\
\text { provision) }\end{array}$ & $\begin{array}{l}\begin{array}{l}\text { No examination } \\
\text { on the substance } \\
\text { of the grounds } \\
\text { (taken as } \\
\text { combined) }\end{array} \\
\text { Direct or indirect } \\
\text { discrimination } \\
\text { might exist - it is } \\
\text { for the national } \\
\text { court to decide. } \\
\text { There is no right to } \\
\text { information for the } \\
\text { rejected applicant } \\
\text { vis a vis the } \\
\text { employer. }\end{array}$ \\
\hline $\begin{array}{l}\text { C-152/11 Johann Odar v Baxter Deutschland } \\
\text { GmbH EU:C:2012:772 [2012] } \\
\text { Facts: Dr. Odar's work contract was } \\
\text { terminated by his employer and he received } \\
\text { compensation. His compensation is reduced } \\
\text { because it is computed on the earliest age of } \\
\text { retirement possible, 54, which he has } \\
\text { exceeded. Being severely disabled, the } \\
\text { possible retirement age for Dr. Odar is earlier } \\
\text { than 54. He claims discrimination both on age } \\
\text { and disability leading to a smaller } \\
\text { compensation. }\end{array}$ & $\begin{array}{ll}\text { - } & \text { Age } \\
\text { - } & \text { Disability }\end{array}$ & $\begin{array}{l}\text { Separate questions on } \\
\text { grounds of age and } \\
\text { disability based on } \\
\text { - Age: Articles } 1 \text { and } 16 \\
\text { of Directive } 2000 / 78 \text { or } \\
\text { justified under } \\
\text { Article } 6(1)(\text { a) } \\
\text { Disability: Articles } 1 \text { and } 16 \\
\text { of Directive } 2000 / 78\end{array}$ & $\begin{array}{l}\text { Separate } \\
\text { examination but } \\
\text { combination } \\
\text { considered. } \\
\text { Discrimination on } \\
\text { grounds of } \\
\text { disability (age taken } \\
\text { into account in the } \\
\text { proportionality } \\
\text { analysis) }\end{array}$ \\
\hline $\begin{array}{l}\text { C-363/12 Z. } v \text { A Government department e } \\
\text { The Board of management of a community } \\
\text { school EU:C:2014:159 [2014] } \\
\text { Facts: a disabled woman born without a uterus } \\
\text { but otherwise able to reproduce resorts to } \\
\text { surrogacy to give birth to her biological child. } \\
\text { She requests maternity leave but is refused the } \\
\text { leave on grounds that she has not been } \\
\text { pregnant. She claims sex and disability based } \\
\text { discrimination. } \\
\text { NB: intersectional discrimination argument } \\
\text { brought at oral proceedings }\end{array}$ & $\begin{array}{l}\text { - Sex } \\
\text { - Disability }\end{array}$ & $\begin{array}{l}\text { Separate questions on } \\
\text { grounds of sex and } \\
\text { disability based on: } \\
\text { Sex: Article } 3 \text { TEU, } \\
\text { Articles } 8 \text { TFEU and } \\
157 \text { TFEU, and/or } \\
\text { Articles } 21,23,33 \text { and } \\
34 \text { of the Charter of } \\
\text { Fundamental Rights of } \\
\text { the European Union } \\
\text { and Art } 4 \text { and } 14 \text { of } \\
\text { Directive } 2006 / 54 \\
\text { Disability: } \\
\text { Article } 10 \text { TFEU, } \\
\text { and/or Articles } 21,26 \\
\text { and } 34 \text { of the Charter } \\
\text { and Articles } 3(1) \text { and } \\
5 \text { of Directive } 2000 / 78\end{array}$ & $\begin{array}{l}\text { Separate } \\
\text { examination: } \\
\text { no discrimination - } \\
\text { outside the scope of } \\
\text { EU law }\end{array}$ \\
\hline $\begin{array}{l}\text { C-423/15 Nils-Johannes Kratzer } v R+V \\
\text { Allgemeine Versicherung AG EU:C:2016:604 } \\
\text { [2016] } \\
\text { Facts: The application of Mr. Kratzer to a } \\
\text { trainee position was rejected. He sent the } \\
\text { employer a demand for compensation against } \\
\text { age discrimination. He was subsequently } \\
\text { invited for an interview, after the employer } \\
\text { claimed that it was not its intention. Mr. } \\
\text { Kratzer refused to go to the interview and } \\
\text { brought a claim of age discrimination to courts. } \\
\text { He later added a claim of age discrimination } \\
\text { when he realised that only female interns had } \\
\text { been selected. }\end{array}$ & $\begin{array}{l}\text { - Sex } \\
\text { - Age }\end{array}$ & $\begin{array}{l}\text { Combined question based } \\
\text { on } \\
\text { - } \\
\text { Age: Article } 3(1)(\text { a) of } \\
\text { Directive 2000/78 } \\
\text { Sex: Article 14(1)(a) of } \\
\quad \text { Directive 2006/54 }\end{array}$ & $\begin{array}{l}\text { Cannot be } \\
\text { considered as a case } \\
\text { of discrimination: } \\
\text { abuse of rights. }\end{array}$ \\
\hline
\end{tabular}


C-443/15 David L. Parris $v$ Trinity College Dublin and Others EU:C:2016:897 [2016]

Facts: Mr. Parris was refused access to a scheme for survivor's benefits by his employer on grounds that he had entered partnership with his same-sex partner past the age of 60 . In fact, the reform authorising same-sex partnerships in Ireland was passed already after Mr. Parris was 60, excluding his earlier application to the survivor's benefits scheme. Mr. Parris brought a claim of discrimination on grounds of age and sexual orientation.

\section{- Sexual orientation \\ - Age \\ Separate and combined \\ questions based on \\ - Sexual orientation: Article 2 of Directive 2000/78 \\ If not:}

- Age: Article 2, in conjunction with Article 6(2) of Directive 2000/78

If not:

- Combination of sexual orientation and age: Article 2 in conjunction with Article 6(2) of Directive 2000/78

C-27/16 Angel Marinkov contre Predsedatel na Darzhavna agentsia za balgarite $v$ chuzhbina EU:C:2016:943 [2016]

Facts: Mr. Marinkov's employment relationship was terminated because restructuration. His position was suppressed while two other similar positions were created to replace his two female colleagues' former positions. No precise criteria were defined to decide who would be maintained or not. Mr. Marinkov thus claims sex discrimination in combination with directive 2000/78/EC.

C-406/15 Petya Milkova v Izpalnitelen

direktor na Agentsiata za privatizatsia $i$

sledprivatizatsionen kontrol EU:C:2017:198 [2017]

Facts: Ms. Milkova's worked as a civil servant in an Agency employing both employees and civil servants. When her work contract was terminated, no authorisation was asked to the labour inspectorate, although this is required for disabled employees. Although Ms. Milkova's mental disability should have obliged her employer to ask for such an authorisation, would she have been an employee, such an authorisation was not mandatory because of her civil servant status. Ms Milkova thus claimed discrimination involving her professional status and her disability.
- Sex

- Unknown ground under Directive 2000/78/EC (the preliminary reference does not mention on which ground)

\section{Combined questions based}

on:

- $\quad$ Article 3(1)(c) of directive 2000/78

- $\quad$ Article 14(1)(c),18 and 25 of directive $2006 / 54$

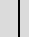

\section{- Disability}

- Civil servant status (not protected under EU law)

\section{Combined questions based} on:

- Article 4 and 7 of

- Article 5(2) UNCRPD

(although the national court clarifies that it understands the differential treatment to be based on the applicant's professional status, it expresses doubts as regards the respect of the principle of equal treatment based on disability) directive 2000/78

\section{No examination on} the substance of the grounds (taken as combined)

It is for the national court to determine whether there is discrimination based on civil servant status within the category of disabled employees:

- Civil servant status is not a ground covered by EU law

- Disability is not the ground on which differential treatment arises

- If the national court find discrimination, the positive action measures afforded to disabled employees must be extended to civil servants. 
Eliminating the cases that have been either rejected or dismissed by the Court (in grey), we are left with a pool of seven multiple discrimination cases since 2007. Among these six preliminary references and one staff (appeal) case where discrimination has been scrutinised, five cases have been formally examined through a single-ground lens, namely Lindorfer (2007), Kleist (2010), Odar (2012), Z. (2014) and Parris (2016). Meister (2012) and Milkova (2017) are the only cases in which the Court has formally adopted a combined approach. ${ }^{94}$ In Lindorfer and Kleist, which involved combined claims of sex and age discrimination, only the sex discrimination claim was examined. ${ }^{95}$ Age was not examined because of not being a protected ground at the time of the facts in Lindorfer, and not being referred by the national court in Kleist.

Hence, the only claims where multiple grounds were really taken into account were Meister,

Odar, Z., Parris and Milkova. ${ }^{96}$ In these cases, the Court either did not examine the multiple discrimination claim on substance (Meister and Milkova) or formally declined to construct a targeted doctrinal framework to assess multiple discrimination. ${ }^{97}$ These decisions, albeit revealing fundamental gaps in the Court's ability to redress multiple discrimination, are nonetheless important because they show some signs of intersectional sensibility at the CJEU even where the language of multiple discrimination is absent. ${ }^{98}$ From the above-mentioned case law, we can trace three ways in which the CJEU has, to varying extents, displayed sensibility for the question of co-constitutive inequalities in multiple discrimination cases. ${ }^{99}$

\section{b. The Contextual Route}

The first indication as to how to assess multiple discrimination cases can be read in Meister. ${ }^{100}$ In this case, the applicant complained because the employer, who had twice rejected her application without hiring any other candidate, refused to disclose information on

\footnotetext{
${ }^{9}$ See chart p 16-18.

${ }_{95}$ ibid.

${ }^{9}$ ibid.

97 ibid.

${ }^{98}$ The expression 'intersectional sensibility' refers to the fact that the Court, despite never using a fully fledged intersectional method, has shown signs of engagement with the problems raised by multiple discrimination and the recommendations of intersectionality theory. See Fredman (n 24) 71-79.

${ }^{99}$ These labels are based on McCall's delineation of inter-, intra- and anti-categorical complexity in L McCall, 'The Complexity of Intersectionality' (Spring 2005) 30 Signs 1771.

${ }^{100}$ See chart pp 16-18.
} 
the reasons for her rejection. Without this information, she could not attempt to establish a prima facie case of discrimination and was thus deprived of a legal remedy, although she alleged multiple discrimination based on sex, age and ethnic origin. Albeit leaving the examination of the issue of discrimination on substance to the national court, the Court opened the door for contextual assessment in discrimination cases. The decision upheld AG Mengozzi's recommendation to 'take[e] into account the wider factual context' when establishing a comparator is impossible. ${ }^{101}$ Because the establishment of a comparator proves difficult in co-constitutive forms of multiple discrimination, the contextual methodology could prove useful, and would also allow to take into account the role of negative ascriptions, harmful stereotypes, stigmatisation and specific kinds of vulnerability. In Meister, however, such a contextual assessment with a view of establishing a prima facie case of discrimination was left to the national court. Hence, the CJEU's insight in the ways the assessment could be conducted remains limited.

\section{c. The Intra-categorical Route: Looking for Modifying Factors of Disadvantage}

Ground-based analyses of discrimination that take into account modifying vectors of disadvantage have been elsewhere called 'capacious interpretation of grounds'. ${ }^{102}$ This approach addresses the relevant 'multiple intersecting power relations' by taking into account 'all aspects of an individual's identity [...] even within one identity ground', '[r]ather than focusing on only one axis of disadvantage and assuming the remaining characteristics are privileged'. ${ }^{103}$ In Odar, a worker resigned after reaching an agreement with his company that it would not affect his compensation rights. ${ }^{104}$ As he was older than 54 at the time of his contract termination, the compensation was calculated based on the earliest retirement date possible. Because of his severe disability, Mr. Odar could retire at age 60, instead of the standard retirement age of 65 . Consequently, his compensation was calculated based on a shorter length of service and was reduced. The earlier retirement date meant that a compensatory measure to accommodate his disability was thus turned into a financial disadvantage. As a result, Mr Odar claimed discrimination based both on age and disability.

\footnotetext{
${ }^{101}$ See ibid: AG Opinion in Case C-415/10 Meister EU:C:2012:217, paras 31, 37, 38.

102 Fredman (n 24) 10.

103 ibid. See CEDAW and CERD (n 20). 'Convention on the Rights of Persons with Disabilities' (adopted 13 December 2006, entered into force 3 May 2008) UNGA Res 61/106.

${ }^{104}$ See chart pp 16-18.
} 
The question of discrimination was split on each ground. Despite this separation, the Court implicitly acknowledged the synergistic effects of age and disability, albeit not using the language of multiple discrimination. It, in fact, introduced age as a modifying factor of disadvantage in the proportionality analysis of the disability discrimination question. By considering the effects of old age on disability, the Court acknowledged 'the risks faced by severely disabled people, who generally face greater difficulties in finding new employment, as well as the fact that those risks tend to become exacerbated as they approach retirement age'. ${ }^{105}$ In the weighted (or infringed) proportionality test that follows, the CJEU also states that '[s]everely disabled people have specific needs, stemming both from the protection their condition requires and from the need to anticipate possible worsening of their condition [because] with advancing age, those financial needs may increase' ${ }^{106}$ In so doing, the Court sheds light on the reinforcing dynamics of the discriminatory effects. Even if age discrimination is not acknowledged per se, it influences the assessment of the effects of the policy on ageing disabled people.

The intra-ground approach thus allows for a more flexible analysis, taking into account modifiers and synergistic factors within a less rigid comparator-based approach to discrimination. ${ }^{107}$ Similar approaches can be fragmentarily detected in the Court's approach to claims that have been brought on single grounds but involve more factors, even though no mention of either 'multiple discrimination' or 'intersectionality' is made. ${ }^{108}$ This has notably been the case regarding discrimination concerning combinations of gender and age, for instance with questions of earlier retirement age limits imposed on women with respect to men or disadvantages in pension benefits due to interrupted labour periods linked to maternity leave. ${ }^{109}$ Cases concerning the survivor's pension benefits in same-sex partnerships similarly showed sensibility in respect of the interactions of sexual orientation and age. ${ }^{110}$ Finally, the famous $P \vee S$ (1996) case shows how an intersectional appreciation of the different

\footnotetext{
${ }^{105}$ See ibid, Case C-152/11 Odar EU:C:2012:772, para 69 (emphasis added).

106 ibid.

${ }^{107}$ Fredman (n 24) 69.

108 See eg Fredman (n 24) 71-72; Fudge and Zbyszewska1 (n 93) 159-160.

109 ibid, 71. See, eg Case C-152/84 Marshall v Southampton Area Health Authority EU:C:1986:84; Case C408/92 Smith v Avdel Systems Ltd. EU:C:1994:349.

110 See Fredman (n 24) 72. See Case C-267/06 Maruko v Versorgungsanstalt der deutschen Bühnen EU:C:2008:179; Case C-147/08 Römer v Freie und Hansestadt Hamburg EU:C:2011:286.
} 
implications of gender status led the Court to acknowledge that gender identity is covered by the protection against sex discrimination. ${ }^{111}$

\section{d. The Inter-categorical Route: Focus on the Intersections}

If the intra-ground approach has been already hinted at by the Court and could be a doctrinal avenue to assess multiple discrimination, other claims have explicitly asked the Court to analyse the intersections of different grounds. Z. and Parris follow this model and will be the object of this and the next section. ${ }^{12}$ In the $Z$. case, the litigators used intersectionality theory to denounce the multiple discrimination arising from a decision to refuse maternity leave to a worker who could not bear a child because of a disability, but who had become a mother via a surrogacy arrangement. While the preliminary reference split the claim of discrimination on grounds of gender and disability, the litigator introduced an intersectional framing at the oral stage. ${ }^{113}$

The Court, however, dissected the question based on each ground and missed the synergistic discriminatory effects produced by the interaction of sex and disability, hence erasing the specific disadvantage of the applicant. In its sex discrimination test, the Court compared the applicant to commissioning fathers, and did not find sex discrimination. This comparison is surprising, as fathers do not benefit from maternity leave in EU law, be they commissioning or not. ${ }^{114}$ Second, in its disability discrimination test, the CJEU compared the applicant to able workers and gave disability a restrictive interpretation as a work impairment, considering that the absence of a uterus for the applicant did not impair her ability to work. Hence, despite asking for an inter-categorical approach, the litigators did not manage to have the Court abandon its strict single-axis approach. In this case, an inter-categorical approach considering the co-exclusionary effects of disability and gender on access to motherhood would have helped to overcome a strictly biological conception of maternity.

3) Parris: A Recent Illustration of the Blind Spots of EU Equality Law

\footnotetext{
${ }^{111}$ See Fredman (n 24) 75. See Case C-13/94 P v S and Cornwall County Council EU:C:1996:170.

112 See chart pp 16-18.

113 This information is based on an interview with David Fennelly.

114 Some jurisprudential precedents had excluded comparison for discrimination assessments concerning maternity. See Case C-177/88 Dekker (n 86).
} 
This section focuses on Parris, the most recent multiple discrimination case at the CJEU and the first to explicitly ask about the combined effects of multiple grounds. In Parris, a rule required workers subscribing to survivor's benefits schemes to enter civil partnership before age 60. Mr Parris was, however, unable to do so, as same-sex partnerships were not recognised in Ireland until after his 60th birthday. Like Mr Parris, same-sex couples older than 60 on the date of entry into force of the Irish Civil Partnership Act in 2015 were excluded from the survivor's benefits scheme by the age limit, while younger same-sex couples could subscribe, and heterosexual couples always had this possibility (pre- as well as post-2015) before turning 60. Understanding the interplay of age and sexual orientation as vectors of the specific exclusion of older same-sex couples in this case is crucial to fully grasp the nature of the discrimination at stake. ${ }^{115}$

The applicant brought a claim before the Irish Labour Court, which referred three questions to the CJEU. First, is the rule at stake discriminatory on grounds of sexual orientation? Second, if not, is the rule at stake discriminatory on grounds of age? Third, if not, does the rule at stake create discrimination arising 'from the combined effect of the age and sexual orientation of a member of the scheme?" ${ }^{116}$ Asking both the either-or and the combination question is obviously a strategy to open as many avenues as possible for legal reasoning on multiple discrimination. At the same time, it risks obfuscating the co-constitutive nature of the multiple discrimination at stake. In fact, the third question seems like a fall-back option in case the first two claims are not recognised. While it is strategically understandable given the absence of an explicit recognition of multiple discrimination at the CJEU and the uncertainties about how to address it, this framing also opens an emergency exit for the Court to avoid confronting the problem of multiple discrimination.

AG Kokott's opinion openly recognised the problem posed by multiple discrimination:

The Court's judgment will reflect real life only if it duly analyses the combination of those two factors, rather than $[\ldots]$ in isolation. ${ }^{117}$

First analysing each ground separately before turning to their combination is conceptually misleading and to some extent self-contradictory in picturing intersectional analysis as a fallback option in case single-ground claims are dismissed. Nonetheless, Kokott's analysis has

\footnotetext{
115 For more detailed accounts on the questions of age discrimination, precarious work and LGBT rights in Europe, see the chapters by A Trydonidou, P Ayoub, B Ter Haar, R Horton and M Bell in this volume.

${ }_{116}$ Case C-443/15 Parris (n 79) para 29.

117 Case C-443/15 Parris (AG Opinion) (n 10).
} 
strategic salience in that it purports to open several ways for legal reasoning on multiple discrimination. She in fact explained:

The combination of two or more different grounds [...] is a feature which lends a new dimension to a case such as this and must be taken duly into account in its assessment under EU law [because] it would be inconsistent with the meaning of the prohibition on discrimination [...] for a situation such as that at issue here to be split and assessed exclusively from the point of view of one or [the] other $[\ldots]$ grounds $[\ldots]$ in isolation. ${ }^{118}$

Kokott subsequently analysed the combination of grounds from the point of view of indirect discrimination and particular disadvantage and conducted an 'infringed' proportionality test:

The combination of two or more $[\ldots]$ grounds $[\ldots]$ may also mean that, in the context $[\mathrm{a}]$ proportionality test, the interests of the disadvantaged employees carry greater weight, which increases the likelihood of undue prejudice to the persons concerned, thus infringing the requirements of proportionality sensu stricto. ${ }^{119}$

Kokott thus suggested a higher standard of judicial review to assess the 'new dimension' created by co-constitutive forms of multiple discrimination. ${ }^{120}$ As cases of multiple discrimination are often less visible and more difficult to identify, this proposal sketches a valid test to assess the harm created by combinations of grounds. However, AG Kokott's opinion fails to propose a detailed method of combined analysis, leaving the practical operationalisation of her infringed proportionality test in the dark. This is problematic as the CJEU lacks guidance on how such a test should unfold. Besides, Kokott's conclusion on the existence of indirect discrimination based on sexual orientation but not age is disputable, as the community affected by the discriminatory rule only encompasses older same-sex couples. ${ }^{121}$ Despite these shortcomings, the identification of, and confrontation with, multiple discrimination at the CJEU constitutes a step forward. ${ }^{122}$

In its decision, the Court, however, did not follow Kokott's recommendation. It first examined both grounds of age and sexual orientation separately, whereas the third question regarding the combination of grounds should have been examined in the first place to do justice to the multiple discrimination claim. The separate examination led to the conclusion that there was

\footnotetext{
118 See chart pp 16-18: Case C-443/15 Parris (AG Opinion) (n 10) paras 4, 153.

119 See ibid, para 157 (emphasis added).

120 ibid.

121 ibid, para 164.

122 Notably, the research commanded by the European Commission has visibly influenced AG Kokott, who cites reports on multiple discrimination. Ibid, fn 76. See also (nn 23 and 24).
} 
no direct discrimination based on sexual orientation because the age limit rule was neutral and did not directly target same-sex couples. The Court then avoided the question of indirect discrimination by invoking national sovereignty on the regulation of marriage and partnerships, while it should have focused on the particularly disadvantageous effects of the rule at stake for older homosexual workers and their partners. Secondly, the Court recognised that there was a differential treatment on grounds of age, however this did not constitute discrimination because it fell into the exceptions allowed by Article 6(2) FED. Thirdly, in a very brief assessment of four paragraphs, the Court dismissed the question about multiple discrimination by refusing to look at the combined effect of two grounds. It acknowledged that 'discrimination may indeed be based on several [...] grounds', yet it refuses to investigate their synergy by arguing that 'there is [...] no new category of discrimination resulting from the combination of more than one of those grounds [...] that may be found to exist where discrimination on the basis of those grounds taken in isolation has not been established'. ${ }^{123}$ This reflects an additive thinking, where two grounds are considered to add up to each other if proven separately, and recalls the infamous DeGraffenreid decision in which US judges refused to create a 'super remedy'. ${ }^{124}$

Hence, the CJEU's reasoning obscures the reality of co-constitutive disadvantage. ${ }^{125}$ Following the recommendations of intersectionality theory, the CJEU should have instead understood that discrimination arises from the co-constitutive effects of two systems of exclusion: the historical exclusion of homosexuals from a large subset of civil and family rights; and the economic marginalisation of older people when retreating from the labour market. Hence it should have lowered the evidence threshold by not requiring each ground to be proven separately. Asking for separate evidence in fact is likely to erase particular disadvantage by raising the evidentiary threshold. ${ }^{126}$ An intersectional frame of analysis has particular added value when the grounds analysed separately are not deemed to amount to discrimination. Their interaction might, in fact, yield sufficient evidence to prove the harm. Instead, the reasoning of the Court completely dismisses this possibility by stating the reverse

\footnotetext{
123 Case C-443/15 Parris (n 79) para 80. The fact that both grounds claimed are protected by the same directive should have made it easier for the Court to examine their interaction.

${ }^{124}$ DeGraffenreid v General Motors Assembly Division, St Louis, 558 F2d 480, C.A.Mo. 8th Cir. (1977), para 143.

125 ibid and Case C-443/15 Parris (n 79) para 80.

126 This evidentiary problem has been recognised elsewhere. See Jefferies $v$ Harris County Community Action Assn 615 F 2d 1025 (5th Cir 1980) and Baylis-Flannery v DeWilde (cob. Tri Community Physiotherapy), [2003] OHRTD No 20.
} 
idea, namely that intersectional discrimination should first be proven based on separate grounds and then in combination. Hence, the conclusion reached by the Court that "where a national rule creates neither discrimination on the ground of sexual orientation nor discrimination on the ground of age, that rule cannot produce discrimination on the basis of the combination of those two factors' is flawed. ${ }^{127}$ Unpacking the synergistic nature of discrimination in Parris helps with understanding the cracks in the CJEU's reasoning. The discriminatory harm is, first, the product of historically anchored gender stereotypes. The principle of survivor's benefits is rooted in the understanding that men are the sole family's breadwinners and that upon their retirement, the (heterosexual) family needs to be sustained through the pension rights accumulated by the male worker over his working life. To ensure the stability of this model, women engaged in non-salaried household work are entitled to the pension rights of their male partners in the event of their early death. This risk-minimising contract, sealed though marriage, has long served to stabilise the social contract between a male breadwinner and a female caregiver. ${ }^{128}$ Since the idea of masculinity is stereotypically paired with heteronormativity, breadwinning and waged work, the breadwinner-caregiver model does not apply to homosexual couples. Therefore, marriage as a stabiliser of heteronormative social relationships serves to exclude homosexual couples from survivor's (and marriage-related) benefits. To understand how the synergistic effects of different systems of exclusion like patriarchy, heteronormativity and ageism interact with society's most anchored organisational structures and in so doing produce complex systems of inequality, we need to look at the historical context of production of norms. This is what an intersectional framework would have helped do in Parris. In refusing to engage with a contextual assessment either through an intra- or an inter-categorical analysis of the case, the CJEU erased the cumulative effect of different systems of inequality. Both its single-ground analysis and its refusal to tackle the combination of grounds were flawed because they ignored that exclusions based on sexual orientation experienced over a lifetime produce consequences which are felt particularly strongly in old age. These exclusions lock out from societal institutions which in turn bars from economic benefits and solidarity while financial dependency increases with ageing. One thing Parris makes clear is that an intersectional framework as a doctrinal tool for analysing complex discriminations is not a superficial

\footnotetext{
${ }^{127}$ Case C-443/15 Parris (n 79) para 81.

128 See C Pateman, The Sexual Contract (Stanford, Stanford University Press, 1988). For an analysis in the EU context, see also U Bełavusaŭ, 'EU Sexual Citizenship: Sex beyond the Internal Market' in D Kochenov, EU Citizenship and Federalism: The Role of Rights (Cambridge, Cambridge University Press, 2017).
} 
demand for theoretical refinement, but rather a practical way to deal with types of discriminations that can hardly redressed through the current doctrine.

\section{Conclusion}

To conclude, even though scholarly research has shown the extent and gravity of intersectional disadvantage, the protection offered by EU anti-discrimination law through the Race Equality and the Framework Equality Directives remains patchy at best. The CJEU, albeit recently invited to fill this gap in Parris, has so far refused to construct an explicit doctrinal framework to deal with the problem of multiple discrimination. As the demonstration in this chapter has shown, the argument of multiple discrimination against women has so far mainly been used to reassert the structural significance of the problem of sex discrimination and the priority given to gender equality on the EU anti-discrimination agenda. Hence, both at the legislative and judicial levels, a full framework to address multiple discrimination transversally across the whole spectrum of grounds is still missing, despite sporadic signs of progressive change.

Furthermore, the lack of consistent terminology across time and space in the EU adds confusion to an already complex debate. Even though the question of multi-dimensional inequality emerged under the label of multiple discrimination in the EU context, it refers to a broader and older debate framed by the concept of intersectionality. A recent linguistic shift in European discussions shows that the issue of multiple discrimination has come to be increasingly considered in relation to intersectionality scholarship. While multiple discrimination remains the sole concept anchored in the 2000 Directives, current discussions about a possible anti-discrimination reform blur the line by referring to both terminologies. Future legislation could make a crucial contribution to this point of debate by bringing needed clarification.

The unclear regulation of the issue of multiple discrimination, as well as its lack of clear definition in the Race and Framework Equality Directives, is problematic because the EU has so far failed to give guidance to Member States on how to redress the pervasive problem of multiple discrimination. As a result, applicants and litigators are often deterred from bringing such cases to court, hence leading to a minimisation of the problem, a lack of judicial attention, and a limited access to justice for victims. 
However, awareness of the harms created by situations of multiple discrimination seems to be increasing. In the very same case in which the CJEU denied judicial recognition to the problem of multiple discrimination, AG Kokott discussed it explicitly in the context of intersectionality scholarship and called for an apposite doctrinal solution. This acknowledgment may well have planted a seed which could give impetus to a renewed debate on the necessity to tackle multiple discrimination and, ultimately to adopt doctrinal and legislative reforms.

In addition, this chapter has demonstrated how the CJEU has shown sensitivity for the issue of intersectionality in its past case law, although not in formal terms. The Court's antidiscrimination jurisprudence in fact indicates some awareness of the existing synergies between the social systems that create and sustain disadvantage. This structural attention to the multi-dimensionality of the phenomenon of discrimination could lead to interesting developments in the future, in particular along the lines of the intra-categorical and contextual approaches delineated in this chapter.

Most importantly, current discussions in the Council suggest a turning point in the debate about multiple discrimination. In line with the growing attention granted to the problem in research and policy-making in the EU, negotiations over the horizontal anti-discrimination reform proposed by the Commission in 2008 most recently shifted to include a comprehensive discussion of the issue of multiple discrimination. Such an explicit legislative recognition would be a première in EU law, and would give the CJEU a clear mandate to tackle this form of neglected and complex discrimination. This change would be a welcome development of EU law given the magnitude and pervasiveness of the phenomenon of multiple discrimination. It could contribute to realising the EU's political ambitions in terms of advancing the human right to equality. 